\title{
PENINGKATAN HASIL BELAJAR MENULIS PUISI MELALUI \\ PENDEKATAN PEMBELAJARAN CTL PADA SISWA KELAS \\ V SEKOLAH DASAR NEGERI 060890 KECAMATAN \\ MEDAN POLONIA
}

\author{
Zulfaridah
}

Surel: zulfaridah@gmail.com

\begin{abstract}
ABSTRAK
Penelitian ini bertujuan untuk meningkatkan hasil belajar siswa pada mata pelajaran Bahasa Indonesia pada materi pokok Menulis Puisi di kelas V SD Negeri 060890 Medan Polonia dengan menggunakan pendekatan Contextual Teaching and Learning (CTL). Subjek penelitian adalah siswa kelas V SD N 060890 Medan Polonia yang berjumlah 23 siswa, terdiri dengan siswa lakilaki 12 anak dan siswa perempuan 11 anak. Pada siklus II diketahui bahwa nilai rata-rata kelas yang diperoleh sebesar 81 . Nilai rata-rata kelas tersebut menunjukkan adanya peningkatan nilai dari siklus I ke siklus II sebesar 8,5 poin. Persentase ketuntasan belajar klasikal siswa pada siklus II sebesar 92\%. Hasil yang diperoleh pada siklus II telah mencapai kriteria keberhasilan yang ditentukan. Hasil belajar yang diperoleh pada siklus II membuktikan bahwa penerapan pendekatan Contextual Teaching and Learning dapat meningkatkan hasil belajar siswa pada pembelajaran menulis puisi di kelas V SD Negeri 060890 Medan Polonia.
\end{abstract}

Kata Kunci: Pendekatan CTL, Hasil Belajar, Menulis Puisi

\section{PENDAHULUAN}

Pada Undang-Undang Sistem Pendidikan Nasional Nomor 20 Tahun 2003, dijelaskan bahwa kurikulum adalah seperangkat rencana dan pengaturan mengenai tujuan, isi dan bahan pelajaran serta cara yang digunakan sebagai pedoman penyelenggaraan untuk mencapai tujuan pendidikan tertentu. Saylor, Alexander, dan Lewis (1974) dalam Hernawan (2007:13) menganggap kurikulum sebagai "segala upaya sekolah untuk mempengaruhi siswa supaya belajar, baik dalam ruangan, kelas, di halaman sekolah, maupun di luar sekolah". Berdasarkan Kurikulum Tingkat Satuan Pendidikan (KTSP), bahasa memiliki peran sentral untuk perkembangan intelektual, sosial dan emosional siswa. Selain itu, bahasa merupakan penunjang keberhasilan dalam mempelajari semua bidang studi karena melalui bahasa siswa dapat saling berbagi pengalaman dan saling belajar.

Salah satu tujuan nasional bangsa Indonesia yang tertera dalam Pembukaan Undang-Undang Dasar 1945 alinea keempat adalah mencerdaskan kehidupan bangsa. Upaya untuk mencerdaskan kehidupan bangsa dapat dilakukan 
melalui pendidikan. Pendidikan memegang peranan penting dalam rangka memperbaiki kualitas Sumber Daya Manusia (SDM). Setiap manusia memiliki hak yang sama untuk mendapatkan pendidikan yang layak. "Pendidikan merupakan usaha sadar yang dilakukan oleh manusia agar dapat mengembangkan potensi dirinya melalui proses pembelajaran". (Munib, 2010:139). Undang-Undang Republik Indonesia Nomor 20 Tahun 2003 tentang Sistem Pendidikan Nasional Bab I pasal 3 menyatakan bahwa: Pendidikan nasional berfungsi mengembangkan kemampuan dan membentuk watak serta peradaban bangsa yang bermartabat dalam rangka mencerdaskan kehidupan bangsa, bertujuan untuk berkembangnya potensi peserta didik agar menjadi manusia yang beriman dan bertaqwa kepada Tuhan yang Maha Esa, berakhlak mulia, sehat, berilmu, cakap, kreatif, mandiri dan menjadi warga negara yang demokratis serta bertanggungjawab (Munib, 2010: 21).

Tujuan pendidikan nasional adalah tujuan pendidikan yang ingin dicapai secara nasional yang dilandasi oleh falsafat suatu negara (Hernawan, 2007: 1.19). Guru dituntut mampu menciptakan proses pembelajaran yang efektif agar mencapai tujuan tersebut. Untuk menciptakan proses pembelajaran yang efektif diperlukan seperangkat perencanaan yang sesuai dengan proses pembelajaran yang diharapkan. Proses pembelajaran harus disesuaikan dengan kurikulum. Kurikulum berfungsi sebagai acuan dalam menetapkan tujuan, isi, bahan, dan strategi pada setiap proses pembelajaran berlangsung (Lapono, 2008: 2.56).

Dengan saling berbagi pengalaman dan saling belajar akan menunjang keberhasilan siswa dalam mempelajari bidang studi yang diajarkan. Keterampilan berbahasa memiliki empat komponen yang saling memengaruhi. Keempat komponen tersebut adalah menyimak (listening skills), berbicara (speaking skills), membaca (reading skills), dan menulis (writing skills) (Tarigan 1981:1 dalam Doyin dan Wagiran 2010:11). Keterampilan menulis sebagai salah satu komponen keterampilan berbahasa harus terus menerus dikembangkan dalam era tekhnologi informasi dan komunikasi yang serba maju.

Menulis merupakan kegiatan yang dilakukan seseorang untuk menghasilkan sebuah tulisan (Santosa, 2007: 6.14). Mata pelajaran Bahasa Indonesia merupakan mata pelajaran yang penting dalam kehidupan sehari-hari. Mata pelajaran Bahasa Indonesia penting karena melalui pelajaran Bahasa 
Indonesia siswa akan memiliki keterampilan menulis, membaca, berbicara dan menyimak. Keempat keterampilantersebut dibutuhkan dalam kehidupan sehari- hari. Selain itu, Bahasa Indonesia merupakan salah satu mata pelajaran pokok yang wajib dikuasai siswa karena bahasa digunakan dalam kehidupan sehari-hari, baik di lingkungan keluarga, sekolah, maupun masyarakat.

Salah satu materi yang ada dalam mata pelajaran Bahasa Indonesia kelas $\mathrm{V}$ adalah menulis puisi. Secara etimologi, istilah puisi berasal dari Bahasa Yunani poeima 'membuat' atau poeisis 'pembuatan', dan dalam Bahasa Inggris disebut poem atau poetry (Aminuddin, 2011:134).Menurut Pradopo (2007: 7) puisi itu mengekspresikan pemikiran yang membangkitkan perasaan, yang merangsang imajinasi pancaindera dalam susunan berirama.

Menulis puisi merupakan bagian dari kompetensi yang harus dimiliki siswa SD, seperti tertera dalam standar kompetensi KTSP kelas V tahun 2006. Standar kompetensi tersebut yaitu siswa diharapkan mampu mengungkapkan pikiran, perasaan dan fakta secara tertulis dalam bentuk ringkasan, laporan dan puisi. Dalam materi menulis puisi siswa dituntut untuk mampu menciptakan puisi. Siswa dalam menulis puisi masih mengalami kesulitan. Siswa harus mencari katakata dengan idenya sendiri yang menyebabkan siswa menjadi kurang tertarik ketika pelajaran Bahasa Indonesia khususnya materi menulis puisi. Hal ini juga terjadi di SD Negeri 060890 Medan Polonia kelas V tempat peneliti melakukan penelitian.

Berdasarkan identifikasi

masalah yang telah diuraikan di atas, maka rumusan masalah yang diajukan peneliti adalah: "Apakah Pendekatan Contextual Teaching and Learning (CTL). Dapat Meningkatkan Hasil Belajar Menulis Puisi pada Siswa Kelas V SD Negeri 060890 Medan Polonia ?’.

Pada bagian ini akan diuraikan mengenai tujuan penelitian. Tujuan penelitian ada dua yakni tujuan umum dan tujuan khusus. Tujuan umum adalah tujuan yang dirumuskan dengan skala yang lebih luas dan bersifat umum. Tujuan khusus adalah tujuan yang dirumuskan dengan skala yang lebih sempit. Pada bagian tujuan umum akan dijelaskan secara umum mengenai tujuan penelitian. Sedangkan pada bagian tujuan khusus akan diuraikan secara rinci mengenai tujuan penelitian. Uraian lebih rinci mengenai tujuan penelitian dapat dibaca pada uraian berikut:

Tujuan umum dilakukannya penelitian ini adalah untuk meningkatkan kualitas pembelajaran 
Bahasa Indonesia di kelas V SD Negeri 060890 Medan Polonia. Tujuan khusus adalah tujuan yang dirumuskan dengan skala yang lebih sempit. Tujuan khusus penelitian ini adalah: (1) meningkatkan hasil belajar siswa dalam pembelajaran Bahasa Indonesia pada materi pokok menulis puisi di kelas V SD Negeri 060890 Medan Polonia dengan menggunakan pendekatan Contextual Teaching and Learning (CTL), (2) meningkatkan aktivitas belajar siswa dalam menulis puisi pada siswa kelas V SD Negeri 060890 Medan Polonia. Penelitian yang dilakukan diharapkan dapat memberikan manfaat secara teoritis maupun praktis. Manfaat teoritis artinya hasil penelitian bermanfaat untuk mengembangkan ilmu pengetahuan. Manfaat praktis bermanfaat bagi berbagai pihak untuk memperbaiki kinerja, terutama bagi sekolah, guru dan siswa. Uraian selengkapnya sebagai berikut:

Manfaat teoritis artinya hasil penelitian bermanfaat untuk mengembangkan ilmu pengetahuan. Manfaat teoritis penelitian ini yaitu menambah referensi di bidang pendidikan, terutama dalam meningkatkan keterampilan menulis puisi pada siswa kelas V sekolah dasar.

Manfaat praktis yaitu manfaat yang bersifat praktik dalam pembelajaran. Manfaat praktis penelitian antara lain:

a. Bagi siswa

Manfaat penelitian ini bagi siswa yaitu: (1) meningkatkan pemahaman siswa dalam menulis puisi, (2) meningkatnya aktivitas dan hasil belajar siswa dalam pembelajaran.

b. Bagi guru

Manfaat penelitian ini bagi guru yaitu memberi masukan bagi guru dalam kegiatan belajar mengajar tentang penggunaan pendekatan pembelajaran Contextual Teaching and Learning (CTL) sebagai alternatif dalam meningkatkan kualitas pembelajaran Bahasa Indonesia.

c. Bagi sekolah

Manfaat penelitian ini bagi sekolah yaitu: (1) memberikan masukan yang positif tentang penelitian tindakan kelas untuk meningkatkan

kualitas pembelajaran di sekolah, khususnya dalam pembelajaran Bahasa Indonesia materi menulis puisi di kelas $\mathrm{V}$, (2) menambah khasanah bacaan tentang pendekatan pembelajaran Contextual Teaching and Learning (CTL) yang biasa.

\section{METODE PENELITIAN}

Penelitian ini menggunakan Penelitian Tindakan Kelas (PTK). Menurut Arikunto (2010:2) Penelitian Tindakan Kelas (PTK) 
merupakan suatu pencermatan terhadap kegiatan belajar berupa sebuah tindakan, yang sengaja dimunculkan dalam sebuah kelas. Penelitian Tindakan Kelas (PTK) dilaksanakan dalam bentuk siklus berulang yang di dalamnya terdapat empat tahapan kegiatan yaitu: perencanaan, pelaksanaan, pengamatan, dan refleksi.

Pelaksanaan Penelitian

Tindakan Kelas (PTK) dimulai dengan siklus pertama yang terdiri dari kegiatan perencanaan, pelaksanaan, pengamatan, dan refleksi. Apabila telah diketahui letak keberhasilan dan hambatan tindakan yang dilaksanakan pada siklus pertama maka peneliti menentukan rencana untuk siklus kedua. Kegiatan pada siklus kedua berupa kegiatan yang sama dengan kegiatan sebelumnya, namun kegiatan pada siklus kedua berupa perbaikan dari siklus pertama. Tambahan perbaikan ditujukan untuk memperbaiki hambatan dan kesulitan yang ditemukan pada siklus pertama. Jika dalam dua siklus indikator kinerja yang dirumuskan telah memenuhi kriteria keberhasilan, maka cukup dilakukan penyimpulan dan pemaknaan hasil tanpa harus menambah siklus.

Subjek penelitian ini adalah siswa kelas V SD Negeri 060890 Medan Polonia, tahun pelajaran 2015/2016. Siswa kelas V SD
Negeri 060890 Medan Polonia berjumlah 25 siswa, jumlah siswa laki-laki sebanyak 13 siswa dan jumlah siswa perempuan sebanyak 12 siswa. Peneliti memilih siswa kelas V SD Negeri 060890 Medan Polonia sebagai subjek penelitian karena berdasarkan hasil pengamatan, siswa kelas V SD Negeri 060890 Medan Polonia mengalami kesulitan pada mata pelajaran Bahasa Indonesia materi menulis puisi. Berdasarkan fakta inilah maka peneliti melakukan penelitian tindakan kelas (PTK) sebagai upaya peningkatan hasil belajar menulis puisi.

\section{HASIL DAN PEMBAHASAN}

Sebelum melaksanakan tindakan siklus I, peneliti melakukan tes pra tindakan terlebih dahulu. Tes pratindakan diikuti oleh 25 siswa, terdiri dari 13 siswa laki-laki dan 12 siswa perempuan. Hasil tes pra tindakan dianalisis untuk mengetahui keadaan awal hasil belajar siswa, sebelum peneliti melakukan tindakan siklus. Tes yang digunakan dalam pra tindakan adalah tes formatif berbentuk uraian. Tes yang dilakukan berupa menulis puisi, namun tanpa keluar kelas untuk melakukan pengamatan langsung kepada objek yang dijadikan tema atau gagasan puisi. Penilaian meliputi kesesuaian judul, isi puisi, pilihan kata, dan rima. Hasil rekapitulasi tes pra tindakan.

Pengambilan data penelitian 
yang dilakukan pada siklus I meliputi data kuantitatif dan data kualitatif. Data kuantitatif dalam penelitian yaitu berupa data hasil belajar siswa. Sedangkan data kualitatif dalam penelitian yaitu berupa hasil pengamatan terhadap aktivitas siswa, performansi guru saat melaksanakan pembelajaran dan kemampuan guru dalam merancang RPP pada siklus I. Pada deskripsi data siklus I akan diuraikan mengenai: (1) data hasil belajar siswa, (2) data hasil pengamatan aktivitas belajar siswa, (3) data hasil pengamatan performansi guru, (4) refleksi siklus I.

Hasil yang diperoleh pada pembelajaran siklus II menunjukkan bahwa pembelajaran menulis puisi pada siklus II sudah berlangsung dengan baik. Berdasarkan hasil yang diperoleh pada pembelajaran siklus II maka dapat diambil keputusan bahwa peneliti tidak perlu melakukan siklus. Hal ini dikarenakan hasil belajar siswa, hasil pengamatan aktivitas siswa, serta performansi guru pada saat merncanakan dan melaksanakan pembelajaran siklus II sudah memenuhi kriteria keberhasilan yang telah ditentukan.

Setelah penelitian tindakan kelas dilakukan maka diperoleh data mengenai hasil belajar, aktivitas siswa, serta performansi guru. Data hasil belajar siswa diperoleh dari tes formatif. Data aktivitas belajar siswa dan performansi guru diperoleh dari pengamatan selama pelaksanaan penelitian siklus I dan II. Pada bagian ini akan diuraikan mengenai hasil penelitian yang diperoleh.

Pada kegiatan tes pratindakan, nilai rata-rata hasil belajar siswa yaitu 59,75. Nilai tersebut belum memenuhi kriteria keberhasilan yaitu $\geq 64$. Siswa yang mencapai ketuntasan belajar hanya 6 siswa atau (24\%) siswa dari 25 siswa. Persentase tuntas belajar klasikal siswa sebelum dilaksanakan tindakan belum memenuhi standar ketuntasan SD Negeri 060890 Medan Polonia yaitu 75\%.

Setelah diadakan tindakan penelitian pada siklus I, terjadi peningkatan pada nilai rata-rata hasil belajar siswa. Pada pelaksanaan tes formatif siklus I diperoleh nilai ratarata kelas sebesar 72,50. Rata-rata hasil belajar menulis puisi setelah diadakan siklus I mengalami peningkatan sebesar 12,75. Nilai rata-rata kelas pada siklus I sudah berada di atas Kriteria Ketuntasan Minimal (KKM) SD Negeri 060890 Medan Polonia yaitu $\geq 64$. Persentase ketuntasan belajar klasikal siswa pada siklus I sebesar $72 \%$. Persentase ketuntasan belajar klasikal siswa belum memenuhi kriteria ketuntasan belajar klasikal yaitu $75 \%$.

Pembelajaran pada siklus I belum dapat dikatakan berhasil 
karena belum mencapai indikator keberhasilan yang ditentukan. Untuk dapat dikatakan berhasil, maka harus mencapai nilai rata-rata kelas minimal 64 dengan persentase ketuntasan belajar klasikal sebesar $75 \%$.

Kurang
perhasilnya
pembelajaran pada siklus I
dikarenakan siswa yang belum
terbiasa dengan penggunaan
pendekatan Contextual Teaching
and Learning. Saat kegiatan di luar kelas, terdapat beberapa siswa yang kurang serius dalam melakukan kegiatan pengamatan terhadap objek dalam menulis puisi. Selain itu, terdapat beberapa siswa yang kurang memperhatikan penjelasan guru sehingga menyebabkan hasil belajar siswa menjadi rendah.

$$
\text { Hasil belajar siswa }
$$
mengalami peningkatan pada pelaksanaan siklus II. Pada pelaksanaan tes formatif siklus II diperoleh nilai rata-rata sebesar 81 dengan persentase ketuntasan belajar klasikal sebesar 92\%. Peningkatan ini terjadi karena pada pelaksanaan pembelajaran siklus II siswa sudah mulai terbiasa dengan penggunaan pendekatan Contextual Teaching and Learning dalam pembelajaran menulis puisi. Siswa sudah mulai serius ketika melaksanakan kegiatan pengamatan objek dalam menulis puisi. Siswa juga sudah tidak malu untuk bertanya dan mengungkapkan pendapatnya. Selain itu, siswa sudah memperhatikan penjelasan guru dengan antusias.

\section{Pembahasan}

Nilai rata-rata hasil belajar siswa pada tes pratindakan yaitu 59,75. Nilai tersebut belum memenuhi kriteria keberhasilan yang telah ditentukan yaitu nilai rata-rata kelas $\geq 64$. Siswa yang tuntas belajar hanya 6 siswa atau 24\%. Sedangkan siswa yang tidak tuntas belajar berjumlah 19 siswa atau $76 \%$. Oleh karena itu, perlu dilakukan tindakan siklus I dan siklus II sebagai perbaikan pembelajaran menulis puisi sehingga hasil belajar siswa dapat mencapai batas ketuntasan SD Negeri V SD Negeri 060890 Medan Polonia Polonia.

Setelah peneliti menerapkan pendekatan Contextual Teaching and Learning (CTL) pada pembelajaran Bahasa Indonesia khususnya materi menulis puisi, hasil belajar siswa mengalami peningkatan. Pada siklus I diperoleh nilai rata-rata kelas sebesar 72,50. Nilai rata-rata tersebut menunjukkan peningkatan dari nilai tes pratindakan ke siklus I sebesar 12,75 poin. Nilai rata-rata kelas pada siklus I telah memenuhi kriteria yaitu $\geq 64$. Persentase ketuntasan belajar klasikal pada siklus I sebesar $72 \%$. Persentase ketuntasan belajar klasikal pada siklus I belum memenuhi 
kriteria keberhasilan yaitu $75 \%$. Berdasarkan data yang diperoleh pada siklus I, hasil belajar siswa pada siklus I belum dapat mencapai kriteria keberhasilan yang ditentukan. Hal tersebut dikarenakan guru kurang mengoptimalkan pemberian motivasi pada siswa.

Pada siklus II diketahui bahwa nilai rata-rata kelas yang diperoleh sebesar 81 . Nilai rata-rata kelas tersebut menunjukkan adanya peningkatan nilai dari siklus I ke siklus II sebesar 8,5 poin. Persentase ketuntasan belajar klasikal siswa pada siklus II sebesar 92\%. Hasil yang diperoleh pada siklus II telah mencapai kriteria keberhasilan yang ditentukan. Kriteria keberhasilan tersebut yaitu nilai rata-rata kelas $\geq$ 64 dengan persentase ketuntasan belajar klasikal minimal $75 \%$. Hasil belajar yang diperoleh pada siklus II membuktikan bahwa penerapan Peningkatan aktivitas belajar tersebut terjadi karena melalui pendekatan Contextual Teaching and Learning (CTL) guru dapat merancang pembelajaran yang terpusat pada siswa.

Selain itu, siswa merasa senang ketika pembelajaran karena pembelajaran tidak hanya dilakukan dalam kelas tetapi juga di luar kelas. Apabila siswa merasa senang dalam pembelajaran maka siswa juga akan termotivasi untuk lebih semangat mengikuti pembelajaran.
Pendekatan Contextual Teaching and Learning dapat meningkatkan hasil belajar siswa pada pembelajaran menulis puisi di kelas V SD Negeri V SD Negeri 060890 Medan Polonia Polonia. Dengan demikian tujuan penelitian dan indikator keberhasilan telah tercapai, rumusan masalah telah terpecahkan, dan hipotesis penelitian telah terbukti.

\section{SIMPULAN}

Penelitian dengan judul "Peningkatan Hasil Belajar Menulis Puisi Melalui Pendekatan Pembelajaran CTL pada Siswa Kelas V Sekolah Dasar Negeri 060890 Medan Polonia" telah dilaksanakan selama dua siklus. Berdasarkan hasil penelitian dan pembahasan yang telah disajikan dapat disimpulkan bahwa penggunaan pendekatan Contextual Teaching and Learning (CTL) telah berhasil meningkatkan kualitas pembelajaran Bahasa Indonesia materi menulis puisi pada siswa kelas V SD Negeri 060890 Medan Polonia. Adapun peningkatan pembelajaran secara rinci disimpulkan sebagai berikut:

1. Penggunaan pendekatan Contextual Teaching And Learning (CTL) dalam pembelajaran menulis puisi pada siswa kelas V SD Negeri 060890 Medan Polonia dapat meningkatkan hasil belajar 
siswa. Peningkatan hasil belajar siswa pada pembelajaran menulis dapat diketahui dari hasil tes pra tindakan, siklus I, dan siklus II.

2. Nilai rata-rata aktivitas belajar siswa pada siklus II telah mencapai kriteria keberhasilan yang ditentukan yakni minimal $75 \%$. Hal tersebut dapat dilihat dari hasil pengamatan terhadap aktivitas belajar siswa. Persentase keaktifan belajar yang diperoleh siswa pada pertemuan pertama siklus II yakni sebesar $84 \%$ dan pada pertemuan 2 meningkat menjadi $87,5 \%$. Nilai rata-rata aktivitas belajar siswa pertemuan I dan pertemuan II pada siklus II yaitu $85,75 \%$ dengan kriteria sangat tinggi. Siswa yang pada pembelajaran siklus I belum bertanya, pada pembelajaran siklus II sudah mulai berani bertanya. Siswa juga sudah mulai berani mengemukakan pendapatnya tanpa ditunjuk terlebih dahulu. Persentase kehadiran siswa pada siklus II sebesar $100 \%$. Hasil tersebut telah mencapai kriteria keberhasilan yaitu kehadiran klasikal siswa minimal $75 \%$.

3. Performansi guru dalam pelaksanaan pembelajaran siklus II telah mencapai kriteria keberhasilan yang ditentukan. Hal tersebut dapat dilihat dari hasil pengamatan performansi guru pada pelaksanaan pembelajaran siklus II. Nilai performansi guru yang diperoleh pada pertemuan pertama sebesar dan 87,08 meningkat menjadi 89,75 pada pertemuan kedua. Berdasarkan nilai performansi tersebut maka diperoleh nilai akhir performansi guru sebesar 88,42 dengan kriteria A. Nilai akhir performansi guru tersebut telah mencapai kriteria keberhasilan performansi guru yaitu minimal 71 dengan kriteria B. Nilai rata-rata kelas pada tes $p$ ratindakan adalah 59,75 dengan persentase ketuntasan sebesar 24\%. Pada siklus I, nilai rata-rata kelas menjadi 72,50 dengan persentase ketuntasan belajar klasikal sebesar $72 \%$. Dengan demikian terjadi kenaikan nilai rata-rata kelas dari tes pratindakan ke siklus I sebesar 12,75 dan kenaikan persentase ketuntasan belajar klasikal sebesar $48 \%$. Setelah dilaksanakan siklus II, nilai rata-rata kelas menjadi 81 dan persentase ketuntasan belajar klasikal menjadi 92\%.

4. Dengan demikian terdapat peningkatan nilai rata-rata kelas dari siklus I ke siklus II sebesar 8,5 dan kenaikan persentase ketuntasan belajar klasikal sebesar 20\%. Persentase ketuntasan belajar yang diperoleh pada siklus II sudah mencapai indikator keberhasilan yang telah ditetapkan yaitu sebesar 75\%. Peningkatan hasil belajar tersebut membuktikan keberhasilan pembelajaran menulis puisi dengan menggunakan pendekatan Contextual Teaching and Learning (CTL).

5. Peningkatan aktivitas belajar siswa terlihat dari hasil pengamatan aktivitas siswa dalam proses pembelajaran. Hasil pengamatan 
tersebut menunjukkan jumlah skor aktivitas belajar siswa pada siklus I yakni sebanyak 299 dengan persentase keaktifan belajar siswa sebesar $74,75 \%$ dengan kriteria tinggi. Aktivitas belajar siswa mengalami peningkatan pada pelaksanaan siklus II. Jumlah skor aktivitas belajar siswa pada siklus II yakni sebanyak 343 dengan persentase keaktifan belajar siswa sebesar $85,75 \%$ dengan kriteria sangat tinggi.

Berdasarkan hasil penelitian yang telah dilakukan, peneliti memberikan saran sebagai berikut:

1. Pendekatan pembelajaran

Contextual Teaching and

Learning (CTL), dapat

dijadikan alternatif pendekatan pembelajaran yang dapat digunakan guru. Berdasarkan hasil penelitian yang telah dilakukan terbukti bahwa pendekatan Contextual Teaching and Learning (CTL) dapat meningkatkan hasil belajar siswa. Oleh karena itu, guru hendaknya menerapkan pendekatan Contextual Teaching and Learning (CTL) dalam proses pembelajaran.

2. Pihak sekolah hendaknya memberikan kesempatan, sarana dan prasarana bagi guru yang hendak melakukan inovasi pembelajaran baik kegiatan pembelajaran yang dilakukan di dalam maupun di luar ruang kelas.

3. Praktisi pendidikan atau peneliti lain diharapkan dapat melakukan penelitian di bidang keterampilan menulis puisi melalui pendekatan yang lain untuk menambah khasanah penerapan pendekatan dalam pembelajaran.

\section{DAFTAR RUJUKAN}

Arikunto, Suharsimi. 1996. Produser Penelitian Suatu Pendekatan Praktek. Jakarta: Rineka Cipta.

Hasibuan dan Moedjino 1996. Proses Belajar Mengajar. Bandung: Remadja Karya.

Hidayat, Kosadi dkk .1987. Strategi Belajar Mengajar Bahasa Indonesia. Bandung: Bina Cipta.

Muhandir. 2001. Ensiklopedia Pendidikan. Malang: UM Press.

Silberman, Melvin 1. 2002. Active Learing, $101 \quad$ Strategi Pembelajaran. Yogyakarta: Yappendis.

Sudjana. 1992. Metoda Stastistik Bandung: Tarsito.

Suriasumantri, Jujun S. 1999. Filsafat Ilmu Sebuah Pengantar Populer. Jakarta: Pustaka Sinar Harapan. 